\title{
Pemberdayaan Pokdakan Tanah Berongga Sido Urep Melalui Budidaya Lele Bioflok Autotrof di Kabupaten Aceh Tamiang
}

\author{
Abdul Latief1*, Agus Putra AS2, Adi Bejo Suwardi3, Baihaqi4 \\ ${ }^{1}$ Prodi Ilmu Manajemen, Fakultas Ekonomi, Universitas Samudra \\ ${ }^{2}$ Prodi Budidaya Perairan Fakultas Pertanian, Universitas Samudra \\ ${ }^{3}$ Prodi Pendidikan Biologi, Fakultas KIP, Universitas Samudra \\ ${ }^{4}$ Prodi Pendidikan Bahasa Inggris Fakultas KIP, Universitas Samudra \\ email: latief@unsam.ac.id
}

\begin{abstract}
Pokdakan Tanah Berongga Sido-Urep is one of the pokdakan that cultivates catfish. The objective of this activity is to develop catfish farming using autotrophic biofloc technology. The target of this activity is 22 members of the pokdakan tanah berongga-sido urep. The main problem faced by the group is the lack of technology and equipment facilities that support catfish farming activities, institutional management, marketing and finance. The method used is participatory rural appraisal. The activities carried out like as 1) Socialization 2) Training, 3) Mentoring and 4) Monitoring and Evaluation. The Activities conducted such as the provision of feed machines, Autotrop biofloc ponds, Feed formulation training and Institutional strengthening. The evaluation results showed the improvement of knowledge from the group members in catfish farming technology. The results of the questionnaire showed that 17 participants (77.2\%) understood all the training materials well, while 5 participants (22.8) understood all the training materials well. The level of satisfaction of the training participants showed that 19 participants $(87 \%)$ were very satisfied with the training provided and 3 participants $(13 \%)$ were quite satisfied with this training. Pokdakan Tanah Berongga-Sido Urep has been able to increase the production through autotrophic biofloc pond technology from $100 \mathrm{~kg} / 1000$ fish seeds to $120 \mathrm{~kg} / 1000$ seeds, accelerating the harvest period from 90 days to 75 days, able to reduce dependence on the use of manufactured feed from $100 \mathrm{~kg} /$ harvest cycle to $85 \mathrm{~kg} /$ harvest cycle and autotrophic biofloc pond technology can reduce soil structure damage.
\end{abstract}

Keywords: Pokdakan Tanah Berongga-SidoUrep, Catfish Cultivation, Autotrof Biofloc Pond, Aceh Tamiang District.

\begin{abstract}
Abstrak
Pokdakan tanah berongga sido urep merupakan salah satu pokdakan yang membudidayakan ikan lele. Tujuan dari kegiatan ini adalah mengembangkan budidaya ikan lele dengan rekayasa teknologi bioflok autotrof. Sasaran kegiatan ini adalah 22 orang anggotapokdakan tanah berongga-sido urep. Permasalahan utama yang dihadapi oleh kelompok adalah kurangnya fasilitas teknologi peralatan yang mendukung aktifitas budidaya lele, manajemen kelembagaan, pemasaran dan keuangan. Metode yang digunakan adalah participatory rural appraisal. Kegiatan yang dilakukan meliputi 1) Sosialisasi kegiatan, 2) Pelatihan, 3) Pendampingan serta 4) Monitoring dan Evaluasi. Bentuk kegiatan meliputi penyediaan mesin pakan, kolam bioflok autotrop, pelatihan formulasi pakan dan penguatan kelembagaan.Hasil evaluasi memperlihatkan adanya peningkatan pengetahuan anggota kelompok dalam teknologi budidaya ikan lele. Hasil kuisioner menunjukkan bahwa 17 orang peserta $(77,2 \%)$ peserta memahami dengan baik seluruh materi pelatihan, sedangkan 5 orang peserta (22,8) cukup memahami seluruh materi pelatihan. Tingkat kepuasan peserta pelatihan menunjukkan bahwa 19 orang peserta (87\%) sangat puas dengan pelatihan yang diberikan dan 3 orang peserta ( $13 \%$ ) cukup puas dengan pelatihan ini. Pokdakan tanah berongga-sidourep telah mampu meningkatkan hasil produksi melalui teknologi kolam bioflok autotrof dari $100 \mathrm{~kg} / 1000$ benih ikan menjadi $120 \mathrm{~kg} / 1000$ benih, mempercepat masa panen dari 90 hari menjadi 75 hari, mampu mengurangi ketergantungan terhadap pemakaian pakan pabrikan dari $100 \mathrm{~kg} / \mathrm{siklus}$ panen menjadi $85 \mathrm{~kg} /$ siklus panen serta teknologi kolam bioflok autotrof mampu mengurangi kerusakan struktur tanah.
\end{abstract}


Kata Kunci : Pokdakan Tanah Berongga-Sido Urep, Budidaya Lele, Kolam Bioflok Autotrof, Kabupaten Aceh Tamiang

\section{PENDAHULUAN}

Peraturan Direktur Jenderal Perikanan Budidaya Kementerian Kelautan dan Perikanan (KKP) tahun 2017 menyebutkan bahwa pokdakan adalah kumpulan pembudidaya ikan yang teroganisir, mempunyai pengurus dan aturan-aturan dalam organisasi kelompok yang secara langsung melakukan usaha pembudidayaan ikan. Pokdakan Tanah Berongga Sido Urep didirikan pada bulan Juni tahun 2011 berdasarkan hasil pemetaan sosial PT Pertamina EP-Field Rantau dengan Universitas Sumatra Utara namun baru mendapatkan SK Dinas Kelautan dan Perikanan (DKP) kabupaten Aceh Tamiang pada bulan Oktober 2013 dengan jumlah anggotanya berjumlah 35 orang. Nugraha dkk (2014) menjelaskan inisiatif pembentukan kelompok ini berawal dari permasalahan ekonomi masyarakat dengan $76 \%$ keluarga didusun Makmur adalah miskin. Anggota kelompok melakukan analisis potensi wilayah yang ada di dusun Makmur dengan tanah berongga yang merupakan jenis tanah liat berwarna putih keras merekah dan tanah ini tidak kering pada musim kemarau, dengan kondisi tersebut kelompok Pokdakan Tanah Berongga-sido urep membuat kawasan pembudidayaan ikan Lele dengan sistem kolam tanah, kolam terpal dan kolam semen. Perkembangan Pokdakan ini mengalami kemajuan sangat pesat, seiring anggota kelompok mendapatkan pelatihan dan pendampingan dari berbagai perusahaan dan instansi. Saat ini Pokdakan Tanah Berongga Sido Urep memiliki 200 kolam terdiri atas 30 kolam pembenihan, 8 kolam batu untuk pembesaran dan 162 kolam tanah untuk pembesaran ikan lele. Omset penjualan ikan lele perbulan yang diperoleh oleh anggota kelompok sebanyak Rp. 6.000.000/bulan. Keseluruhan anggota kelompok melakukan budidaya ikan lele menggunakan kolam tanah berdampak buruk terhadap penataan lingkungan. Untuk meminimalisir kelemahan yang dialami oleh anggota kelompok dalam kegiatan budidaya ikan lele, diperlukan adanya sistim budidaya ikan lele yang efektif meningkatkan produktifitas, mempercepat masa panen dan mengurangi penggunaan lahan lebih luas yang dikenal dengan sistem budidaya bioflok autotrof. Dengan begitu, biaya produksi berkurang dan waktu yang diperlukan relatif lebih singkat jika dibandingkan dengan budidaya secara konvensional. Pernyataan ini juga didukung oleh pendapat Faridah dkk (2019) yang menyebutkan bahwa pembesaran ikan lele yang inovatif dan produktif adalah melalui sistim bioflok autotrof. Sementara Sudaryati dkk (2017) menjelaskan bahwa sistem bioflok autotrof merupakan metode budidaya ikan lele yang sudah cukup modern, teknologi ini sekarang sudah banyak dipakai oleh para pembudidaya ikan lele karena mampu mengurangi biaya produksi. Pada penjelasan lainnya, Setiawan (2016) mengungkapkan bahwa sistim bioflok dapat dilakukan tanpa pergantian air dan kontrol ekologinya adalah berupa bakteri bioflok yang dikondisikan, tidak bergantung dari sinar matahari, menggunakan bahan organik serta aerasi penuh dan kuat. Sedangkan Gemaperta (2015) menyebutkan keistimewaan sistim kolam bioflok autotrof waktu budidaya relatif singkat, modal relatif rendah, ramah lingkungan dan hemat penggunaan air dan pakan. Dibagian lain Boyd, C.E (1991) menyebutkan sistem bioflok autotrof dalam kolam budidaya didominasi oleh alga (fitoplankton) dengan memanfaatkan sinar matahari sebagai sumber energi sehingga pertumbuhannya tergantung pada ketersediaan sinar matahari. fitoplankton mampu hidup dengan baik dan dominan di kolam dengan kandungan bahan organik rendah. 


\section{METODE PENGABDIAN}

Metode yang akan digunakan untuk pelaksanaan kegiatan ini adalah dengan model Participatory Rural Appraisal yaitu sutau metode pendekatan dalam proses pemberdayaan dan peningkatan partisipasi masyarakat yang penekanannya pada keterlibatan masyarakat dalam keseluruhan kegiatan yang dilaksanakan. Adapun tahapan kegiatan program pengembangan produk unggulan daerah yang dilakukan adalah sebagai berikut: koordinasi kegiatan dalam rangka menyampaikan rencana pelaksanaan kegiatan untuk kelompok sasaran. Tim pengabdi menjelaskan secara detail rincian dan jadwal kegiatan kepada dinas pangan, kelautan dan perikanan kabupaten acehtamiang, pemerintahan kecamatan karang baru, kepala desa, ketua dan anggota Pokdakan Tanah Berongga Sido Urep serta masyarakat kampung kebun tanjung seumantoh. Kemudian tahap selanjutnya adalah sosialisasi kegiatan yang bertujuan memberikan informasi secara menyeluruh kepada pihak pihak yang terlibat dalam kegiatan ini dengan metode diskusi langsung. Tahapan berikutnya adalah penyerahan bahan habis pakai berupa peralatan untuk pembuatan dua unit kolam bioflok autotrof berukuran 3 meter dan satu unit mesin pakan pelet. Selanjutnya tahapan pendampingan berupa pembuatan 2 (dua) unit kolam bioflok autotrof secara swadaya oleh masingmasing anggota kelompok pelatihan pembuatan pakan pelet, dan penataan kelembagaan serta tahapan monitoring dan evaluasi untuk memastikan kegiatan ini berjalan sesuai dengan target yang direncanakan.

\section{HASIL DAN PEMBAHASAN}

berongga sido urep melalui budidaya lele bioflok autotrof diikuti oleh seluruh anggota kelompok, perangkat desa, babinsa, perwakilan pemerintahan kecamatan dan dinas terkait.
A. Tahapan Sosialisasi

Dalam tahapan sosialisasi ini tim pengabdi bersama dengan mitra sasaran menyepakati rincian pendampingan yang akan dilakukan. Kadis pangan, kelautan dan perikanan kabupaten Aceh Tamiang (Bp. Safuan SP) dalam sambutannya dihadapan kasie PM kantor camat karang baru, danramil 02/karang baru, kepala desa dan perangkat lainnya mengapresiasi program pendampingan yang dilakukan oleh Universitas Samudra bersumber dari DRPM Ristek-BRIN tahun 2020 dan pemerintahan kabupaten Aceh Tamiang akan bersinergi bagi terwujudnya kampung kebun tanjung seumantoh sebagai sentra budidaya lele di kabupaten Aceh Tamiang sekaligus menjadi pusat pembelajaran (training center) bagi para pembudidaya ikan lele dan menjadi salah satu produk unggulan bagi kabupaten Aceh Tamiang pada tahun 2022

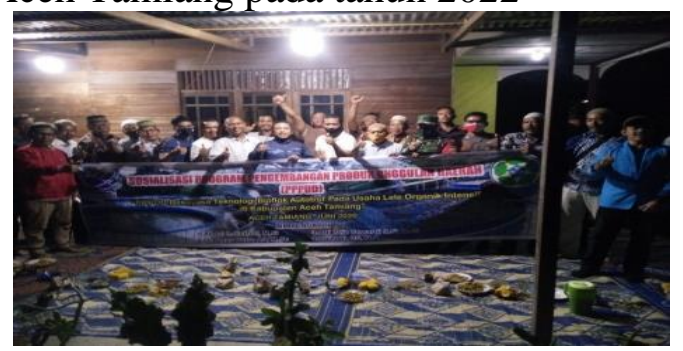

Gambar 1. Sosialisasi Kegiatan

B. Perakitan Mesin Pakan Pelet

Untuk memenuhi ketercukupan pakan bagi anggota pokdakan tanah berongga sido urep, tim pengabdi menyediakan mesin pakan pelet bagi mitra sasaran. Mesin pakan pelet ini memiliki kapasitas produksi $80 \mathrm{~kg} / \mathrm{jam}$.

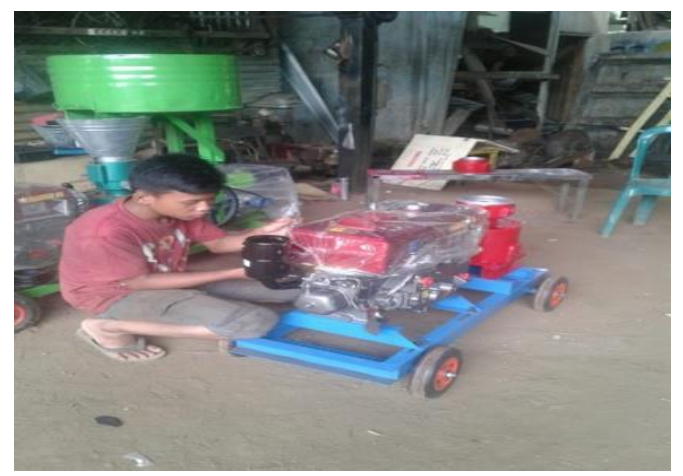

Gambar 2. Perakitan Mesin Pakan Pelet 
C. Uji Coba Mesin Pakan Pelet

Tim pengabdi melakukan uji coba mesin pakan pada tanggal 22 Juli 2020 bersama dengan pengurus dan anggota pokdakan tanah berongga sido urep. Hasil uji coba memperlihatkan bahwa pakan yang dihasilkan dalam kondisi kering dan layak untuk dikonsumsi oleh ikan lele berukuran $5 \mathrm{~cm}$ keatas. Untuk menghasilkan pakan ikan dalam kondisi basah maka komposisi bahan bakunya harus sesuai. Mesin pakan yang telah diuji coba beserta peralatan lainnya di tempatkan pada gudang milik pokdakan dan akan dilakukan serah terima melalui BAST.

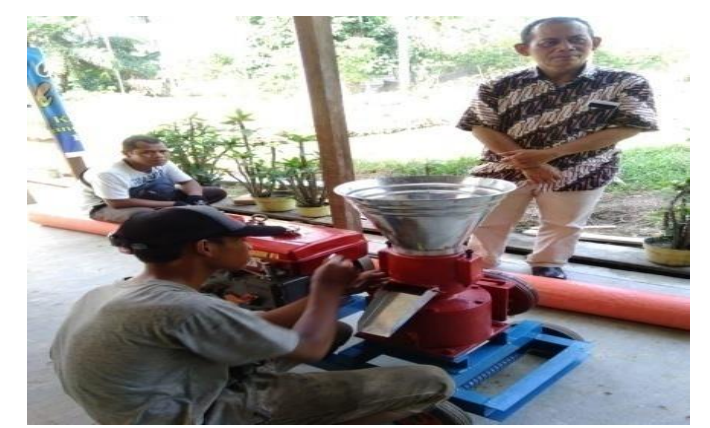

Gambar 3. Uji Coba Mesin Pakan Pelet

D. Pelatihan pembuatan bioflok autotrof

Tim pengabdi menyelenggarakan pelatihan budidaya ikan lele menggunakan rekayasa teknologi bioflok autotrof dengan pemateri Bp. Ibnu Shahidir M.Sc dari balai perikanan budidaya air payau (BPBAP) Ujung Batee Aceh Besar tanggal 11-12 Juli 2020. Dalam pelatihan ini pemateri menjelaskan secara detail budidaya ikan lele dengan sistim kolam bioflok autotrof serta tahapan dan mekanisme budidaya ikan lele dengan teknologi tersebut seperti pembentukan air selama 2 minggu dengan cara diberikan pupuk MPK sebanyak $20 \mathrm{gram} / \mathrm{m}^{3}$ Probiotik RABAL, Bakteri rombak amoniak, ditambahkan dengan kapur halus sebanyak 100gr s/d 250gr per $\mathrm{m}^{3}$. Aerasi selalunya diberikan $1 \mathrm{x}$ per minggu

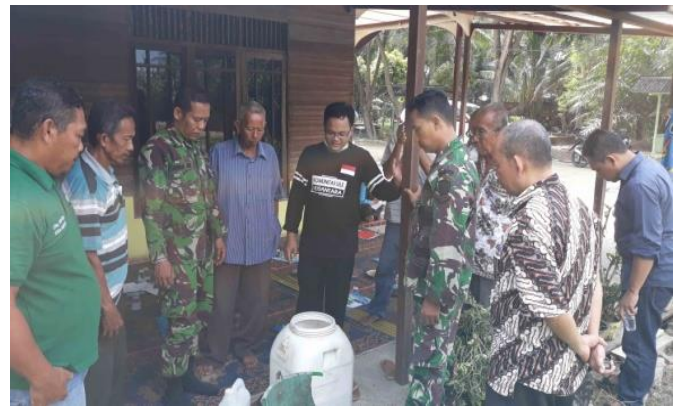

Gambar 4. Pelatihan Pembuatan Bioflok Autotrof

\section{E. Teknik Perakitan Kolam Bioflok Autotrof}

Pada tanggal 22 Juli 2020, tim pengabdi menjelaskan teknik pembuatan kolam bioflok autotrof Dalam penjelasannya disebutkan bahwa kolam bioflok autotrof berbeda dengan kolam bioflok heterotrof dimana kolam bioflok autotrop tidak menggunakan atap seng dan hanya ditutupi dengan paranet sehingga cahaya matahari tidak langsung terkena pada air kolam tersebut. Dalam kesempatan ini tim pengabdi juga menjelaskan takaran air yang ideal untuk kolam bioflok autotrof serta besaran benih yang ditebar pada kolam itu

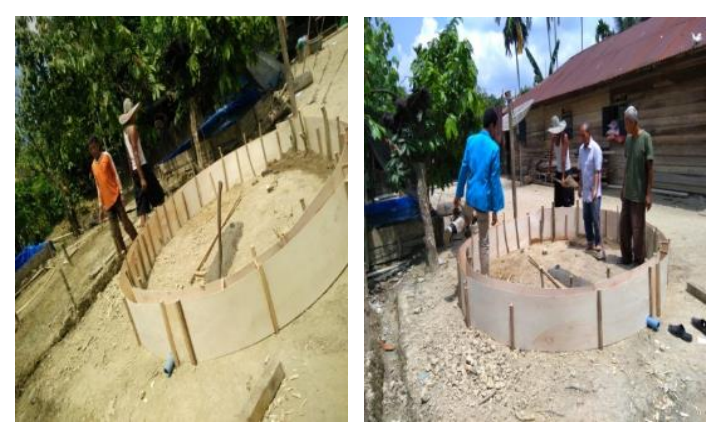

Gambar 5. Pembuatan Plang Cetakan Kolam Biolfok

\section{F. Perakitan Kolam Bioflok Autotrof}

Tim pengabdi memulai pembuatan kolam bioflok autotrof sebanyak dua unit pada salah satu anggota kelompok. Ukuran kolam bioflok autotrof yang dibuat adalah diameter 3 dengan kapasitas benih yang ditebar adalah 5.000 ekor. Jangka waktu penyelesaian kolam bioflok adalah tiga hari mulai dari tahap pembuatan tapak kolam, pemasangan pipa pembuang dan 
rangka kolam bioflok. Pekerja yang terlibat adalah anggota kelompok sendiri. Saat ini pembuatan tapak kolam, rangka besi penyangga, pipa pembuang dan pemasangan terpal sudah selesai dikerjakan oleh anggota kelompok

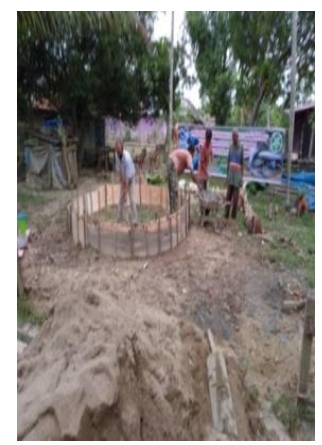

(a)

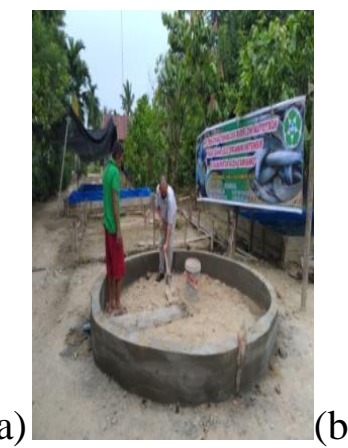

(c)

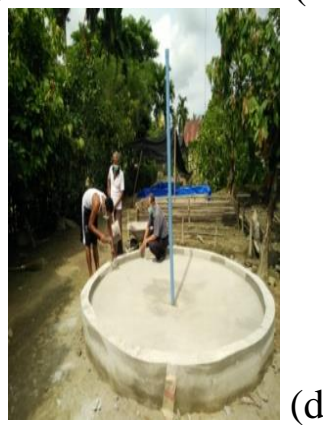

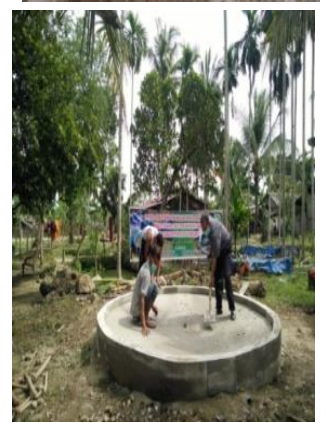

b)

Gambar 6. Tahapan Perakitan Kolam Bioflok Autotrof

Hasil pemantauan yang dilakukan oleh tim pengabdi terlihat dua unit kolam bioflok autotrof telah selesai dikerjakan dan saat ini menunggu ketersediaan probiotik, molase dan kapur dolomit yang akan ditabur pada kedua kolam itu. Penggunaan bahan baku itu bertujuan untuk menumbuhkan probiotik sebagai salah satu makanan bagi bibit ikan lele, membunuh kuman yang ada pada air serta menetralkan ph air.
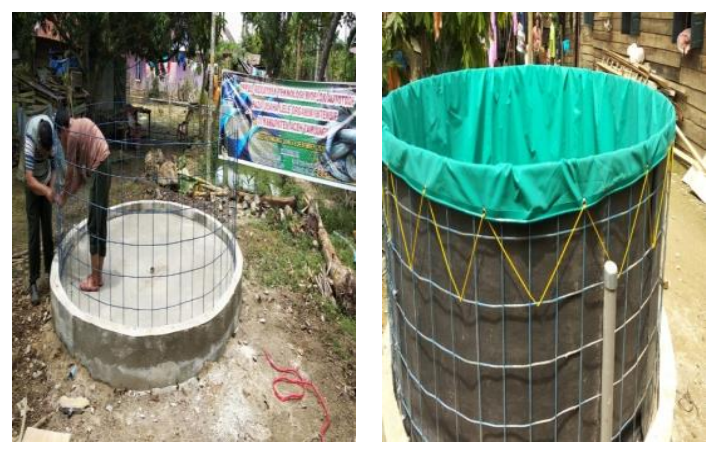

Gambar 7. Kondisi Terkini Kolam Bioflok Autotrof

G. Pelatihan Manajemen Kelembagaan Kelompok

Pada tanggal 29 Juli 2020, tim pengabdi melakukan pelatihan manajemen bagi seluruh anggota pokdakan tanah berongga sido urep. Dalam pelatihan ini, tim pengabdi menginggatkan kembali tentang pentingnya sebuah manajemen dalam sebuah kelompok baik itu manajemen administrasi dan keuangan. Tim pengabdi memeriksa secara keseluruhan bukti dokumen administrasi yang dimiliki oleh kelompok ini mulai dari buku saku, buku kas, buku pencatatan penjualan produk, buku tamu, buku notulensi, dokumen AD/ART, rencana kerja tahunan kelompok, rencana strategis kelompok dan buku pencatatan iuran bulanan anggota kelompok.

$\mathrm{H}$. Monitoring Kegiatan

Tim Pengabdi melakukan monitoring pada pokdakan tanah berongga-sido urep dalam rangka memastikan kegiatan PPPUD berjalan dengan baik. Kegiatan monitoring di fokuskan pada kolam bioflok autotrof yang digunakan untuk budidaya ikan lele dengan jumlah benih yang ditebar pada kedua kolam tersebut sebanyak masing-masing 5000 ekor. Keseluruhan benih merupakan hasil pemijahan dari kelompok itu sendiri dengan masa panen ditargetkan pada hari ke 60 s.d 75. Hasil penjualan ikan lele dimasukkan kedalam kas kelompok.
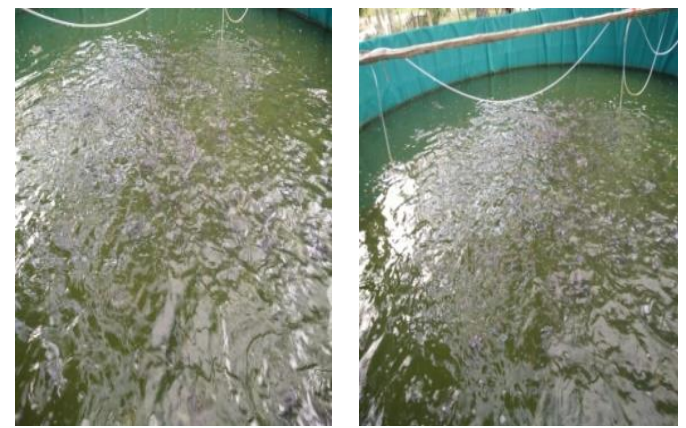

Gambar. 8 Monitoring Kolam Bioflok Autotrof 
Hasil monitoring menunjukkan bahwa ukuran benih ikan lele sudah mencapai 6 $\mathrm{cm}$ dan semuanya dalam kondisi baik dengan tingkat kematian yang rendah. Pakan yang digunakan adalah pelet ukuran 781-1 dan PF-1000 sebanyak $20 \mathrm{~kg}$ untuk ukuran ikan 1-5 cm serta 781-1 sebanyak $65 \mathrm{~kg}$ untuk ukuran 6-30 cm

I. Evaluasi Kegiatan

Tim Pengabdi Universitas Samudra melakukan evaluasi kegiatan pengabdian pada pokdakan tanah berongga sido urep. Berdasarkan hasil pengamatan dan diskusi dengan pengurus tidak ditemukan kendala dalam pelaksanaan kegiatan PKM ini. Ukuran benih ikan lele yang terpantau sudah mencapai 8-10 inch dengan tingkat kematian 3\%. Ketua pokdakan tanah berongga sido urep memprediksi hasil panen mencapai $600 \mathrm{~kg}$ sesuai dengan jumlah benih yang ditabur sebanyak 5000 ekor/kolam. Hasil evaluasi memperlihatkan adanya peningkatan pengetahuan anggota kelompok dalam teknologi budidaya ikan lele. Hasil kuisioner menunjukkan bahwa 17 orang peserta $(77,2 \%)$ peserta memahami dengan baik seluruh materi pelatihan, sedangkan 5 orang peserta $(22,8)$ cukup memahami seluruh materi pelatihan. Tingkat kepuasan peserta pelatihan menunjukkan bahwa 19 orang peserta (87\%) sangat puas dengan pelatihan yang diberikan dan 3 orang peserta ( $13 \%$ ) cukup puas dengan pelatihan ini. Pokdakan tanah berongga-sido urep telah mampu meningkatkan hasil produksi melalui teknologi kolam bioflok autotrof dari $100 \mathrm{~kg} / 1000$ benih ikan menjadi 120 $\mathrm{kg} / 1000$ benih, mempercepat masa panen dari 90 hari menjadi 75 hari, mampu mengurangi ketergantungan terhadap pemakaian pakan pabrikan dari 100 $\mathrm{kg} / \mathrm{siklus}$ panen menjadi $85 \mathrm{~kg} / \mathrm{siklus}$ panen serta teknologi kolam bioflok autotrof mampu mengurangi kerusakan struktur tanah

\section{SIMPULAN}

Berdasarkan pelaksanaan kegiatan pengabdian kepada masyarakat dapat disimpulkan bahwa:

a. Pengurus dan anggota pokdakan tanah berongga sido urep memahami budidaya ikan lele dengan sistim kolam bioflok autotrof dan teknik pembuatan pakan pelet

b. Adanya peningkatan hasil produksi dengan menggunakan kolam bioflok autotrof dari $100 \mathrm{~kg} / 1000$ benih pada kolam tanah/batu menjadi $120 \mathrm{~kg} / 1000$ benih.

c. Teknologi kolam bioflok autotrof mampu mempercepat masa panen ikan lele dari 90 hari pada kolam tanah/batu menjadi 75 hari.

d. Teknologi kolam bioflok autotrof mampu mengurangi ketergantungan pemakaian pakan pabrikan dari 100 kg untuk satu siklus panen menjadi $70 \mathrm{~kg}$ pakan per satu siklus panen di kolam bioflok autotrof

e. Teknologi kolam bioflok autotrof mengurangi kerusakan struktur tanah karena sistim kolam bioflok autotrof dapat digunakan pada lahan yang sempit

\section{UCAPAN TERIMAKASIH}

Penulis mengucapkan terima kasih kepada Direktorat Riset dan Pengabdian kepada Masyarakat, Kementerian Riset, Badan Riset dan Inovasi Nasional yang telah mendanai kegiatan pengabdian kepada masyarakat melalui skema Program Pengembangan Produk Unggulan Daerah tahun 2020 dengan nomor kontrak 083/SP2H/PPM/DRPM/2020 tanggal 06 April 2020. Penulis juga mengucapkan terima kasih kepada Rektor Universitas Samudra, Pemerintah Kabupaten Aceh Tamiang, Dinas Pangan, Kelautan dan Perikanan kabupaten Aceh Tamiang, Pemerintahan Kecamatan Karang Baru, Koramil 02 Karang Baru, Pemerintahan Kampung Kebun Tanjung Seumantoh, 
Pokdakan Tanah Berongga Sido Urep, Fakultas Ekonomi, Fakultas Pertanian, Fakultas KIP dosen serta mahasiswa/i yang terlibat dalam kegiatan ini.

\section{DAFTAR PUSTAKA}

[1] Boyd.C.E. 1991. Water Quality Management in Ponds for Aquaculture. Birmingham Publishing. Alabama.

[2] Dinas Kelautan dan Perikanan Kabupaten Aceh Tamiang 2019.

[3] Faridah, Diana, S, Yuniati. Budidaya Ikan Lele Dengan Metode Bioflok Pada Peternak Ikan Lele Konvensional. CARADDE: Jurnal Kepada Masyarakat. Vol. 1 No. 2, Februari 2019. https://doi.org/10.31960/caradde.vli 2.74 .

[4] Gemaperta. 2015. Cara Budidaya Ikan Lele dengan Sistem Bioflok. http://www.gemaperta.com/2015/02 /cara budidaya-ikan-lele-dengansistem-bioflok.html

[5] Nugraha, Iswantara Adi, Baihaqi, Agus Nur Aji, Sugiono, Dedi Zikrian. 2014. "Si Kumis Pembawa Berkah" Best Practice Program CSR PT Pertamina EP-Field Rantau Dalam Pengembangan Budidaya Lele di Dusun Makmur Kampung Kebun Tanjung Seumantoh Kecamatan Karang Baru Kabupaten Aceh Tamiang". Jakarta: CV Global Express

[6] Peraturan Direktur Jenderal Perikanan Budidaya Nomor 53/PER-DJBP/2017 tentang Petunjuk Teknik Penyaluran Bantuan Pemerintah Sarana Budidaya Pada Kelompok Pembudidaya Ikan Tahun 2017. Kementerian Kelautan dan Perikanan

[7] Setiawan, Ariqoh, R, Tivani, P, Pipih, L. Pudjiastuti, I. Bioflokulasi Sistem Teknologi Budidaya Lele tebar Padat Tinggi Dengan Kapasitas 1 m3/750 ekor Dengan FlockForming Bacteria. Inovasi Teknik Kimia, Vol. 1. No. 1, April 2016 Hal: 45-49

[8] Sudaryati, D, Heriningsih, S, Rusherlistyani. Peningkatan Produktivitas Kelompok Tani Ikan Lele Dengan Teknik Bioflok. Jurnal Pengabdian dan Pemberdayaan Masyarakat Volume 1 No. 2 September 2017. 